\title{
The Utilization Areas of Cabergoline in Veterinary Gynecology
}

\author{
$\odot$ Kudret YENILMEZ ${ }^{1 *}, \odot$ Nihal EREN ${ }^{2}$
}

\author{
1 Namık Kemal Üniversitesi Veteriner Fakültesi Doğum ve Jinekoloji A.B.D. N.K.Ü. Değirmenaltı Yerleşkesi, Namık Kemal Mah. \\ Kampüs Cad.No:01 59030 TEKİRDAĞ \\ 2 Countryvet Veteriner Kliniği, Göktürk, Eyüp, İstanbul
}

Received 26.04.2018 Accepted 14.04.2019

\begin{abstract}
Cabergoline is a potent dopamine agonist and a synthetic ergot derivative, and it acts by inhibiting prolactin secretion from the pituitary gland. It reduces the amount of plasma prolactin and inhibits progesterone secretion at the same time. Because of these effects, it has found a widespread area of use in the treatment of hyperprolactinemic disorders both in the human medicine and veterinary medicine.
\end{abstract}

Keywords: cabergoline, veterinary, gynaecology

\section{Introduction}

Prolactin is a hormone in the polypeptide structure that is secreted from specific lactotroph cells in the adenohypophysis. The main function of the prolactin is the onset and continuation of lactation; however, numerous of its tasks have been reported both inside and outside the reproductive system. The secretion of prolactin is under control of tonic inhibition of prolactin inhibitory factors. The most important prolactin inhibitory factor is dopamine. Dopamine inhibits adenylate cyclase by binding to the dopamine D2 receptors on lactotroph membranes and reduces the prolactin release. In this review, indications of cabergoline in veterinary gynaecology were evaluated by a clinician. It is aimed to draw attention to the importance of cabergoline and to shed light on the works that can be planned in the future.

\section{Cabergoline}

Cabergoline (CAB) (1-[(6-allelylergolin-8 b-yl)carbon- yl]-1-[3-(dimethylamino)propyl]-3-ethyl-urea) is a potent dopamine-2 (D2) receptor stimulant and synthetic ergot derivative. It creates an effect by inhibiting the prolactin secretion from the pituitary gland. ${ }^{1,2}$

Cabergoline is the newest dopamine agonist used in the treatment of hyperprolactinemic disorders both in human and veterinary medicine. The inhibition of prolactin secretion occurs via dopamine. Cabergoline has high selectivity and affinity against the dopamine $\mathrm{D} 2$ receptors that are in pituitary prolactin secreting cells and acts through these receptors. ${ }^{3,4}$ Cabergoline inhibits prolactin secretion in vivo and in vitro pathways and constitutes a stronger prolactin inhibition than other dopamine agonists. It has been reported in the studies carried out on rats that the treatment of single-dose $0.6 \mu \mathrm{g} / \mathrm{kg} \mathrm{CAB}$ reduce the concentrations of prolactin for 6 days, and the $C A B$ application inhibits the progesterone secretion in pregnant cats and dogs. ${ }^{3-7}$

\footnotetext{
* Corresponding author: : Kudret YENILMEZ e-posta : kyenilmez@nku.edu.tr, Namık Kemal Üniversitesi Veteriner Fakültesi
} 

Utilization Areas Of Cabergoline In Veterinary Gyne-
cology

\section{Estrus Induction in Bitches}

Bitches are monoestrus type animals that are not dependent on the season. In general, they reach puberty at 6-14 months of age. The time between two standing heats is 7 months on average and varies between 5-12 months. ${ }^{89}$ The bitches enter the anestrus period after the diestrus period of the cycle. The anoestrus period is long and approximately 120 (40-270) days. Duration of this time may vary depending on the races and the individuals. ${ }^{10}$ The prolongation of the anestrus period is an infertility cause and is divided into two categories as the primary and secondary anestrus. The primary anestrus is the state that the female dog does not have any estrus until 24 months of age, and the secondary anestrus is the state that it does not have oestrus even though 10-18 months have passed after the previous estrus period. ${ }^{9}$

One of the drugs used in bitches for the termination of an anestrus to form estrus is $\mathrm{CAB}$ which is a dopamine agonist. Cabergoline is an ergot alkaloid and has an anti-prolactinergic effect. ${ }^{11,12}$ Suppression of prolactin secretion via dopamine agonists shortens the duration of anestrus and induces the estrus. ${ }^{13}$ It has been reported that the use of $\mathrm{CAB}$ in the treatment of both primary and secondary anestrus cases in dogs induces estrus and provides a high pregnancy rate. Cabergoline is recommended at $5 \mu \mathrm{g} / \mathrm{kg}$ doses to stimulate the estrus in dogs and reported to be effective also at low doses $(0.6 \mu \mathrm{g} / \mathrm{kg}) .{ }^{14-17}$ Unlike dogs, $\mathrm{CAB}$ has not been shown to be effective in inducing estrus in cats. $^{5}$

\section{Termination of Pregnancy Dogs and Cats}

In dogs, prolactin is the luteotropic hormone in the second half of the luteal phase. Prolactin provides the continuity of progesterone by supporting the corpus luteum. Cabergoline, which has an anti-prolactin effect, suppresses luteal functions, causing the decrease of the progesterone concentration and the termination of the pregnancy. ${ }^{6-18,19} \mathrm{Cab}$ ergoline is effective in the second half of pregnancy for the termination of the pregnancy in dogs, and it can be used to terminate advanced and middle term pregnancies. ${ }^{20}$

Onclin et al. ${ }^{21}$ reported that the treatment of pregnant dogs between 25 and 40 days by subcutaneous injection of $\mathrm{CAB}$ for 5 days at $1.65 \mu \mathrm{g} / \mathrm{kg}$ dose displayed a $1 / 4$ abortion at 25 th day, $4 / 6$ at 30 th day and 5/5 at 40th day. Moreover, it was reported that the abortion was achieved by the oral use of $160 \mu \mathrm{g}$ of CAB for 7 days after the 40th day of pregnancy and no side effects were observed. ${ }^{22}$ It has been reported that $\mathrm{CAB}$ can be used in combination with PGF2 $\alpha$ analogues in abortion prophylaxis in dogs. This combina- tion is effective from 25th day of the pregnancy in which is applied at $5 \mu \mathrm{g} / \mathrm{kg}$ orally for $9-10$ days whereas $1 \mu \mathrm{g} / \mathrm{kg}$ subcutaneous cloprostenol is used at 28th and 32nd days of the pregnancy. ${ }^{23}$

Because of the harmfull side effects, the uses of estradiol and PGF2 $\alpha$ has been reported to be unsafe in preventing pregnancy in cats, hence cabergoline and aglepristone are better tolerated. ${ }^{24}$ Verstegen et al. ${ }^{6}$ indicates that there is no adverse effect or behavioural disturbance in the cats on the 30th day of gestation, at dose of $1.65 \mu \mathrm{g} / \mathrm{kg}$ subcutaneous injection of Cabergoline for five consecutive days and $80 \%$ abortion is available. Cabergoline is effective in termination of pregnancy in female cats between 34th and 42th days of pregnancy, when it is used alone, however the combination with PGF2 $\alpha$ is more effective between 25th and 40nd days of pregnancy. ${ }^{25}$

\section{Cystic Endometrial HyperplasiaPyometra Complex Treatment in Queen and Bitch}

Cystic endometrial hyperplasia-pyometra complex (CEH-P) is a disease characterized by purulent fluid accumulation in uterine lumen, cystic dilatation and endometrial hyperplasia in endometrial gland. This case is often seen during the diestrus period, since the cycle is under effect of the influence of progesterone. The frequency of this disease in cats is lesser than those in dogs. ${ }^{26}$

The most important luteotropic hormone in dogs is prolactin. Cabergoline is revealed to be inhibiting the action of prolactin and reducing the plasma progesterone concentration. ${ }^{21}$ In the medical treatment of CEH-P, CAB is used to reduce the serum progesterone concentration (luteolytic effect) and its combination with prostaglandins is recommended to relieve the uterine contents. England et al. ${ }^{27}$ found that the combination of CAB-prostaglandin $(5 \mu \mathrm{g} /$ $\mathrm{kg}$ of $\mathrm{CAB}$ once a day for 10 days, and $5 \mu \mathrm{g} / \mathrm{kg}$ cloprostenol for 3 times SC. in 3 days intervals) decreased plasma progesterone concentration, increased vaginal secretion and reduced uterine diameter. Jena et al. ${ }^{28}$ reported that the most effective treatment protocol for their studies comparing various treatment protocols in pyometra cases of dogs was using cloprostenol ( $1 \mu \mathrm{g} / \mathrm{kg}$ SC. 7 days) in combination with $\mathrm{CAB}(5 \mu \mathrm{g} / \mathrm{kg}$ oral 7 days).

It has been reported that the dopamin agonist CAB $(5 \mu \mathrm{g} /$ $\mathrm{kg}$ oral) can be used alone, combined with prostaglandins or combined with anti-progestins, a rapid luteolysis is provided by the combination of PGF2 $\alpha$ and CAB and the cervix is opened in 24-48 hours, in pyometra cases of cats. ${ }^{26}$

\section{Pseudo-Pregnancy Treatment in Dogs}

Pseudo-pregnancy (PSP) is a common syndrome characterized by nesting, gaining weight, growth in udders, 
increasing milk secretion and maternal behaviour in non-pregnant dogs at the end of the metestrus stage. It may show subclinical or clinical courses. Although the exact physiopathology of the PSP is not fully understood, it has been determined that prolactin hormone levels increase, whereas progesterone hormone levels decrease and it occurs in 6-12 weeks after estrus. ${ }^{29,30}$

Diuretics, progestagens, estrogen, and androgen combinations have been used in the medical treatment of pseudo-pregnancy, however, their usage is contraindicated due to the incidence and severity of side effects. Today, prolactin antagonists are effective in the treatment of symptoms within the next 10 days from the start of treatment. ${ }^{31}$ These drugs have been proven to decrease the level of prolactin, lower the serum levels and thus regress udder gland development, reducing pseudo-pregnancy behaviours. ${ }^{32}$ It was reported that, in the treatment of pseudo-pregnant dogs, application of daily $5 \mathrm{mg} / \mathrm{kg}$, prolactin antagonist,CAB for 5 days was highly effective and no side effects were observed. ${ }^{33-35}$

\section{Treatment of Mammary Hyperplasia in the Cats}

In cats, fibroepithelial udder hyperplasia is a benign disease characterized by progesterone related sudden and rapid fibroglanduler proliferation of one or more mammary glands. ${ }^{36}$ It is reported that this is more common in young female cats but may be seen in male cats. ${ }^{3}$ This disease is often found in animals treated with progesterone or analogues. Progesterone antagonists (aglepristone) and prolactin inhibitors (cabergoline) can be used to treat the disease. Or ovariohysterectomy may be recommended. Medical treatment of this disease is frequently recommended in cats especially that are breed for production. ${ }^{36-38,39}$

In mammary hyperplasia cases with milk secretion, it was reported that successful results were gained with the combined use of Aglepristone (two days a week for three weeks, at the dose of $15 \mu \mathrm{g} / \mathrm{kg}$, subcutaneously) and CAB (at the dose of $5 \mu \mathrm{g} / \mathrm{kg}$ once a day per os, at the first week). ${ }^{40}$

\section{Utilization of Cabergoline in Drying Off the Dairy Cows}

Dairy cows need a dry period between the two lactations to provide high milk yield. ${ }^{41}$ This period, in which the udders of the cows are rested between the two lactation periods and not milked for the last 45-60 days of the pregnancy, is called the dry period, and the process at the beginning of this period is called drying off. In order to dry the cows off from the milking, there are methods such as intermittent milking, not evacuating the milk in the udder completely or sudden cease of milking. ${ }^{42}$ In recent years, it has been reported that, as an alternative to conventional drying off methods, successful results have been obtained with a single $\mathrm{CAB}$ injection in transition to the drying off phase. ${ }^{41-43,44}$ Cabergoline is a high-affinity ergot derivative for D2 dopamine receptors, whose dopaminergic effects cause the inhibition of prolactin secretion. Therefore, as a result of studies carried out considering $\mathrm{CAB}$ as a potential drying off molecule, it was concluded that the intramuscular injection of a single dose of $5.6 \mathrm{mg}$ of CAB on the cows, which gives over $16 \mathrm{~kg}$ of milk in the transition to dry period, Cabergoline treatment positively influences dry period mammary health and reduces risk factors for animal welfare. ${ }^{44}$

In similar studies, it was reported that the same dose of $\mathrm{CAB}$ facilitated the drying of the udder gland and udder gland involution, reduced prolactin release and leakage from the udder, and prolonged the resting time after the drying off. ${ }^{41-43}$ Cabergoline treatment will be beneficial because it accelerates mammary involution and decreases milk secretion in the transition to dry period.

\section{Conclusion}

As a result, $\mathrm{CAB}$ has found a utilization area in veterinary gynaecology, especially in the medical treatment of various gynaecological disorders of carnivorous, and it is advantageous for it to have fewer side effects than other hormone drugs. However, it is not used in dairy cattle in our country as it is used in European countries. Since the $\mathrm{CAB}$ is thought to be useful as a medicine to increase the health and comfort of the cows to be dried off, to increase the number of the studies in this area and to use it in cattle in our country is deemed to be beneficial.

\section{References}

1- Colao A, Di Sarno A, Sarnacchiaro F, et al. Prolactinomas resistant to standard dopamine agonists respond to chronic cabergoline treatment. Int J Clin Endocrinol Metab. 1997; 82(3): 876-883

2- Kaya S. Üremeyi Etkileyen Hormonlar In: Kaya S, ed. Veteriner Farmakoloji 4. Baskı Ankara Medisan Yayınevi 2007:81

3- Balçık O, 2007. Hiperprolaktinomide kabergolinin düşük doz ve kısa dönem idame tedavisinin etkinliğinin araştırılması. T.C. Saglık Bakanlıgı Dr. Lütfi Kirdar Kartal Egitim ve Arastırma Hastanesi 2 2. Kadın Hastalıkları ve Dogum Klinigi Uzmanlık Tezi

4- Colao A, Di Sarno A, Landi ML, et al. Macroprolactinoma shrinkage during cabergoline treatment is greater in naive patients than in patients pretreated with other dopamine agonists: a prospective study in 110 patients. Int J Clin Endocrinol Metab. 2000; 85(6):2247-2252. 
5- Jochle W, Arbeiter K, Post K, Ballabio R. Effects on pseudo-pregnancy, pregnancy and interoestrous intervals of pharmacological suppression of prolactin secretion in female dogs and cats. J Reprod Fertil. 1989; 39:199-207

6- Verstegen JP, Onclin K, Silva LD, et al. Abortion induction in the cat using prostaglandin F2 alpha and a new anti-prolactinic agent, cabergoline. J Reprod Fertil. 1993; ( 47): 411-417.

7- Eguchi K, Kawamoto K, Uozumi T, et al. Effect of Cabergoline, a Dopamine Agonist, on Estrogen-Induced Rat Pituitary Tumors. Endocr J. 1995; 42(3): 413-420.

8- Concannon PW. Reproductive cycles of the domestic bitch. Anim Reprod Sci. 2011; 124(3): 200-210.

9- NakD, NakY, Simsek G. Comparison of the use of cabergoline and gonadotrophin to treat primary and secondary anoestrus in bitches. Aust Vet J. 2012; 90(5): $194-$ 196.

10- Kalkan C, Horoz H, 2001. Pubertas ve Seksüel Sikluslar In: Alaçam E, ed. Evcil Hayvanlarda Doğum ve İnfertilite 3. Baskı Ankara Medisan Yayınevi 2001: 23-40

11- Rains CP, Bryson HM, Fitton A. Cabergoline. Drugs. 1995; 49(2): 255-279.

12- Günay A, 2015. Köpeklerde Östrus Siklusunu Uyarma Yöntemleri. Acta Vet Eurasia. 2015; 41(2): 238-244.

13- Kutzler MA. Estrus induction and synchronization in canids and felids. Theriogenology. 2007; 68(3):354374.

14- Gobello C, Castex G, Corrada Y. Use of cabergoline to treat primary and secondary anestrus in dogs. JAVMA. 2002; 220(11): 1653-1654.

15- Verstegen JP, Onclin K, Silva LDM, et al. Effect of stage of anestrus on the induction of estrus by the dopamine agonist cabergoline in dogs. Theriogenology. 1999; 51(3): 597-611.

16- Rota A, Mollo A, Marinelli L, et al. Evaluation of cabergoline and buserelin efficacy for oestrous induction in the bitch. Reprod Domest Anim. 2003; 38(6): 440-443.

17- Cirit U, Bacinoglu, S, Tas M, et al. Use of a decreased dose of cabergoline to treat secondary anoestrus in bitches. Bull Vet Inst Pulawy. 2007; 51(1):43-46

18- Gobello C. Dopamine agonists, anti-progestins, anti-androgens, long-term-release $\mathrm{GnRH}$ agonists and anti-estrogens in canine reproduction. Theriogenology. 2006; 66(6): 1560-1567.

19- Wanke MM, Romagnoli S, Verstegen J, Concannon PW. Pharmacological approaches to pregnancy termination in dogs and cats including the use of prostaglandins, dopamine agonists, and dexamethasone In: Concannon PW, England G, Verstegen J and C. Linde-Forsberg, ed.Recent Advances in Small Animal
Reproduction, Publisher: International Veterinary Information Service (www.ivis.org), Ithaca, New York, USA.. This document is available on-line at www.ivis. org. 2002; Document No. A1223.0802.

20- Post K, Evans LE, Jöchle W. Effects of prolactin suppression with cabergoline on the pregnancy of the bitch. Theriogenology. 1998; 29(6): 1233-1243.

21- Onclin K, Silva LD, Donnay I, et al. Luteotrophic action of prolactin in dogs and the effects of a dopamine agonist, cabergoline. J Reprod Infertil. 1992; (47):403-409.

22- Arbeiter K, Flatscher C. Induction of abortion in the bitch using cabergoline (Galastop). Kleintierpraxis. 1996; $41: 747$

23- Eilts BE. Pregnancy termination in the bitch and queen. Top Companion Anim Med. 2002; 17(3): 116123

24- Wiebe, VJ, Howard, JP. Pharmacologic advances in canine and feline reproduction. Top Companion Anim Med. 2009; 24(2): 71-99.

25- Erünal-Maral N, Aslan S, Findık M, et al. Alfaprostol $\left(\right.$ Gabbrostim $\left.^{\text {tw }}\right)$ induction of abortion in queens by administration of cabergoline (Galastop ${ }^{\text {tx }}$ ) solely or in combination with the PGF2 $\alpha$ analogue. Theriogenology. 2004; 61(7): 1471-1475

26- Hollinshead F, Krekeler N. Pyometra in the queen: To spay or not to spay? J Feline Med Surg. 2016; 18(1): 21-33.

27- England GCW, Freeman SL, Russo M. Treatment of spontaneous pyometra in 22 bitches with a combination of cabergoline and cloprostenol. Vet Rec. 2007; 160: 293-296.

28- Jena B, Rao KS, Reddy KCS, et al. Comparative efficacy of various therapeutic protocols in the treatment of pyometra in bitches. Vet Med. 2013; 58(5): 271-276.

29- Gobello C, De La Sota RL, Goya RG. A review of canine pseudocyesis. Reprod Domest Anim. 2001; 36(6): 283-288.

30- Tsutsui T, Kirihara N, Hori T, et al. Plasma progesterone and prolactin concentrations in overtly pseudopregnant bitches: a clinical study. Theriogenology. 2007; 67(5): 1032-1038.

31- Mir F, Fontfaonne A. Management of pseudopregnancy lactation refractory to medical treatment in bitches Point Veterinaire. 2013; 44(334): 6-9.

32- Giesenberg S. Pseudopregnancy in the bitch. Aust Vet P. 2004; 34(4): 164-168.

33- Harvey MJA, Cauvin A, Dale M, et al. Effect and mechanisms of the antiprolactin drug cabergoline on pseudopregnancy in the bitch. J Small Anim Pract. 1997; 38(8):36-339.

34- Baştan A, Fındık M, Erunal N, et al. The use of 
cabergoline for treatment of pseudopregnancy in dogs with the purpose of suppressing lactation. Reprod Domest Anim. 1998; 33(2): 4953.

35- Sathiamoorthy T, Kulasekar K, Joseph C, et al. Clinical management of pseudopregnancy in bitches with cabergoline. Indian Vet J. 2007; 84(2): 184185.

36- Dvojkovic N, Macesic N, Bacic G, et al. Feline fibroepithelial hyperplasia (FEH) treatment options. Kleintierpraxis. 2015; 60(5): 237-243

37- Wehrend A, Hospes R, Gruber AD. Treatment of feline mammary fibroadenomatous hyperplasia with a progesterone-antagonist. Vet Rec. 2001; 148(11): 346.

38- MacDougalL LD. Mammary fibroadenomatous hyperplasia in a young cat attributed to treatment with megestrol acetate. Can Vet J. 2003; 44(3): 227-229

39- Concannon PW, Verstegen J. Some unique aspects of canine and feline female reproduction important in veterinary practice. In Proc.: 3rd World Congress of the World Small Anim. Vet. Assoc. 11-14 May 2005. Mexico City, Mexico.

40- Uçmak M, Enginler SÖ, Gündüz MC, et al. Treatment of Feline Mammary Fibroepithelial Hyperplasia with the Combination of Aglepristone and Cabergoline. Acta Vet Eurasia. 2011; 37(1): 69-74.

41- Boutinaud M, Isaka N., Lollivier V, et al. Cabergoline inhibits prolactin secretion and accelerates involution in dairy cows after dry-off. J Dairy Sci. 2016; 99(7): 5707-5718.

42- Özyurtlu N, Doğruer G, 2016. Memenin Fizyolojisi In: Kaymaz M. , Fındık M. , Rişvanlı A. , Köker A, ed.Evcil Hayvanlarda Meme Hastalıkları 1. Baskı Malatya Medipres Matbaacılık Yayıncılık Ltd. Şti. 2016: 23-35

43- Bach A, De-Prado A, Aris A. The effects of cabergoline administration at dry-off of lactating cows on udder engorgement, milk leakages, and lying behavior. J Dairy Sci. 2015; 98(10): 7097-7101.

44- Bertulat $\mathrm{S}$, Isaka $\mathrm{N}$, de Prado A, et al. Effect of a single injection of cabergoline at dry off on udder characteristics in high-yielding dairy cows. J Dairy Sci. 2017; 100(4): 3220-3232. 